\title{
Razlika u pojavnosti ranih komplikacija perkutanog zračenja raka vrata maternice između pacijentica s planiranim liječenjem 2D i 3D tehnikom
}

1 Dorjana Vidmar

${ }^{1}$ Adem Hajredini

${ }^{1}$ Klinika za ženske bolesti i porode, KBC Zagreb

\section{Sažetak}

Liječenje raka vrata maternice ovisi o mnogim faktorima pa je tako jedna od metoda izbora, osim kirurškog liječenja, i radioterapijsko liječenje. Radioterapija je vještina uporabe ionizirajućeg zračenja u liječenju zloćudnih te nekih dobroćudnih bolesti, a cilj joj je s pomoću zračenja uništiti tumorske stanice te pri tome sačuvati okolno zdravo tkivo, u čemu veliki značaj ima 2D radioterapija, a u današnje vrijeme i 3D radioterapija ${ }^{1}$.

Cilj istraživanja bio je utvrditi razliku u pojavnosti ranih komplikacija odnosno reakcija na perkutano zračenje između pacijentica čije je liječenje planirano 2D tehnikom i pacijentica čije je liječenje planirano 3D tehnikom. U istraživanju smo usporedili rezultate liječenja 40 pacijentica koje su bolovale od raka vrata maternice (stadij II.B ili III.B). Kod 20 od njih liječenje je planirano 2D tehnikom, a ostalih 20 3D tehnikom. Istraživanje je provedeno kao sondaža podataka kako bi se utvrdilo postoje li razlike u pojavnosti ranih komplikacija teleterapije raka vrata maternice između pacijentica čije je liječenje planirano 2D i 3D tehnikom, što bi ukazalo na potrebu istraživanja na većem broju pacijentica. lako se očekivala znatna razlika između navedenih načina planiranja, kako u odgovoru na liječenje tako i u učestalosti komplikacija, istraživanjem smo prikazali da se to ipak nije dogodilo.

Ključne riječi: rak vrata maternice, planiranje 2D radioterapije, planiranje 3D radioterapije, rane komplikacije perkutanog zračenja

Datum primitka: 04.10.2016.

Datum prihvaćanja: 15.10.2017.

DOI: $10.24141 / 1 / 3 / 2 / 8$

Adresa za dopisivanje:

Dorjana Vidmar

Vitasovićeva poljana 10, 10000 Zagreb

Tel.: +385995163197

E-pošta: dorjana.vidmar19@hotmail.com 


\section{Uvod}

Radioterapija se tijekom stoljeća etablira kao važan oblik onkološke terapije. Označuje primjenu ionizirajućeg zračenja u cilju postizanja korisnoga biološkog djelovanja i učinka u terapijske svrhe ${ }^{1}$. U ovom ćemo radu objasniti primjenu 2D i 3D radioterapije u liječenju raka vrata maternice te ćemo opisivati prednosti i nedostatke navedenih tehnika, njihove sličnosti i nedostatke te poboljšani učinak liječenja.

Pojavom suvremenih uređaja za vanjsko zračenje otvara se mogućnost liječenja ne samo primarnog tumora nego i metastaza u limfnim čvorovima. Prvi podaci povezani s liječenjem raka vrata maternice sežu u 1908. godinu, kada je po prvi puta primijenjena intrakavitarna terapija. Usporedno s tehnološkim razvojem radioterapijskih uređaja razvijale su se i nove metode u planiranju zračenja te je tako 80-ih godina prošloga stoljeća bilo moguće primjenjivati jedino 2D terapiju zbog ograničenih hardverskih i softverskih sustava, no brzim napretkom tehnologije omogućeno je konstruiranje 3D sustava za planiranje. Kao rezultat napretka tehnologije nameće se kvalitetnija i složenija provedba terapije, uvođenje koncepta CT simulacije, 3D planiranja i konformalne radioterapije. Najvažnija je karika kod provođenja radioterapijskog liječenja kvaliteta života pacijenta, koja, dakako, ovisi o izboru primjene 2D ili 3D radioterapije ${ }^{1}$.

Perkutana radioterapija, drugim nazivom i teleterapija, vrsta je radioterapije gdje je izvor zračenja udaljen od pacijenta ${ }^{1}$. Ovom se vrstom zračenja uništavaju stanice na rubu tumora koje su bolje oksigenirane i kao takve radiosenzitivnije. Tumor se smanjuje i omogućuje se još bolja opskrba središnjeg dijela tumora krvlju. Tako središnji dio tumora postaje osjetljiviji na terapiju intrakavitarnim zračenjem koja slijedi nakon perkutane radijacije $^{3}$.

Općenito u radioterapiji razlikujemo uređaje za planiranje radioterapije te uređaje za provođenje radioterapije. U procesu planiranja radioterapijskog liječenja sudjeluju stručnjaci iz mnogih zdravstvenih polja, kao što su specijalist radioterapije i onkologije, specijalist radiologije, diplomirani inženjer medicinske fizike, prvostupnik radiološke tehnologije i medicinske sestre. Svi oni u tom složenom procesu planiranja pokazuju svoje terapeutske i tehničke vještine ${ }^{4}$.

Radioterapijski uređaj jest uređaj s pomoću kojeg odabiremo i definiramo najpovoljnije geometrijske para- metre snopa zračenja. Dijaskopskim rendgenskim snopom simulira se terapijski snop te liječnik može vidjeti ciljni volumen i organe rizika koji ga okružuju. Kolimator omogućava dobivanje asimetričnih polja, ali i zaštitu organa i tkiva koji se nalaze u okolici tumora. Četiri lasera markiraju tri okomite ravnine koje se sijeku u izocentru (točka u kojoj se sijeku os rotacije akceleratora i os terapijskih snopova) ${ }^{2}$.

CT uređaj jest uređaj za odabir najpovoljnijih geometrijskih parametara snopa zračenja, tj. omogućuje nam izradu CT snimke za potrebe računalnog planiranja terapije. Komponente su od kojih se sastoji: CT skener, laser za pozicioniranje bolesnika i obilježavanje referentnih točaka te računalna programska podrška za 3D planiranje i virtualnu simulaciju. Sve se CT snimke digitalno obrađuju te se očitavaju u računalnim programima za simuliranje radioterapijskih polja i time se pridonosi velikoj preciznosti te se dobivaju informacije o strukturama od interesa².

Radioterapijsko liječenje provodi se uz pomoć linearnog akceleratora koji se sastoji od višeslojnog kolimatora te uređaja za provjeru polja zračenja. Višeslojni kolimator omogućuje zračenje s prilagođenim poljem zbog toga što se lamele raspoređuju po zadanom obliku i tako štite okolne strukture u procesu zračenja.

Kod 2D planiranja radioterapijskog tretmana neizostavna je upotreba konvencionalnog RTG simulatora s pomoću kojeg odabiremo i definiramo najpovoljnije geometrijske parametre snopa zračenja, a dijaskopskim rendgenskim snopom simuliramo terapijski snop.

2D planiranje zračenja i konvencionalna radioterapija provode se primjenom dva do četiri zračna (nasuprotna) snopa čiji se parametri (dimenzije, oblik polja, kut snopa) određuju s pomoću klasičnog RTG simulatora. Namještanje bolesnika na simulator mora biti istovjetno namještanju bolesnika na aparat za zračenje jer se proračun ukupne doze koja će se primijeniti izračunava na osnovi prikaza konture tijela, tumora i rizičnih organa na jednom referentnom CT presjeku. Kod 2D planiranja i provođenja konvencionalne radioterapije potrebno je u projekciji sredine polja uzeti konturu cijeloga volumena tijela ako se radi više polja koja se u dubini tijela preklapaju i zatim se na osnovi toga izračunavaju doze polja zračenja. Ovom tehnikom zdrava tkiva dobivaju znatno veću dozu zato što je teže postići visoku konformalnost doze na ciljni volumen.

3D planiranje provodi se na temelju niza CT presjeka na kojima je moguće precizno definiranje kontura tumora te rizičnih organa čijom se rekonstrukcijom u programu 


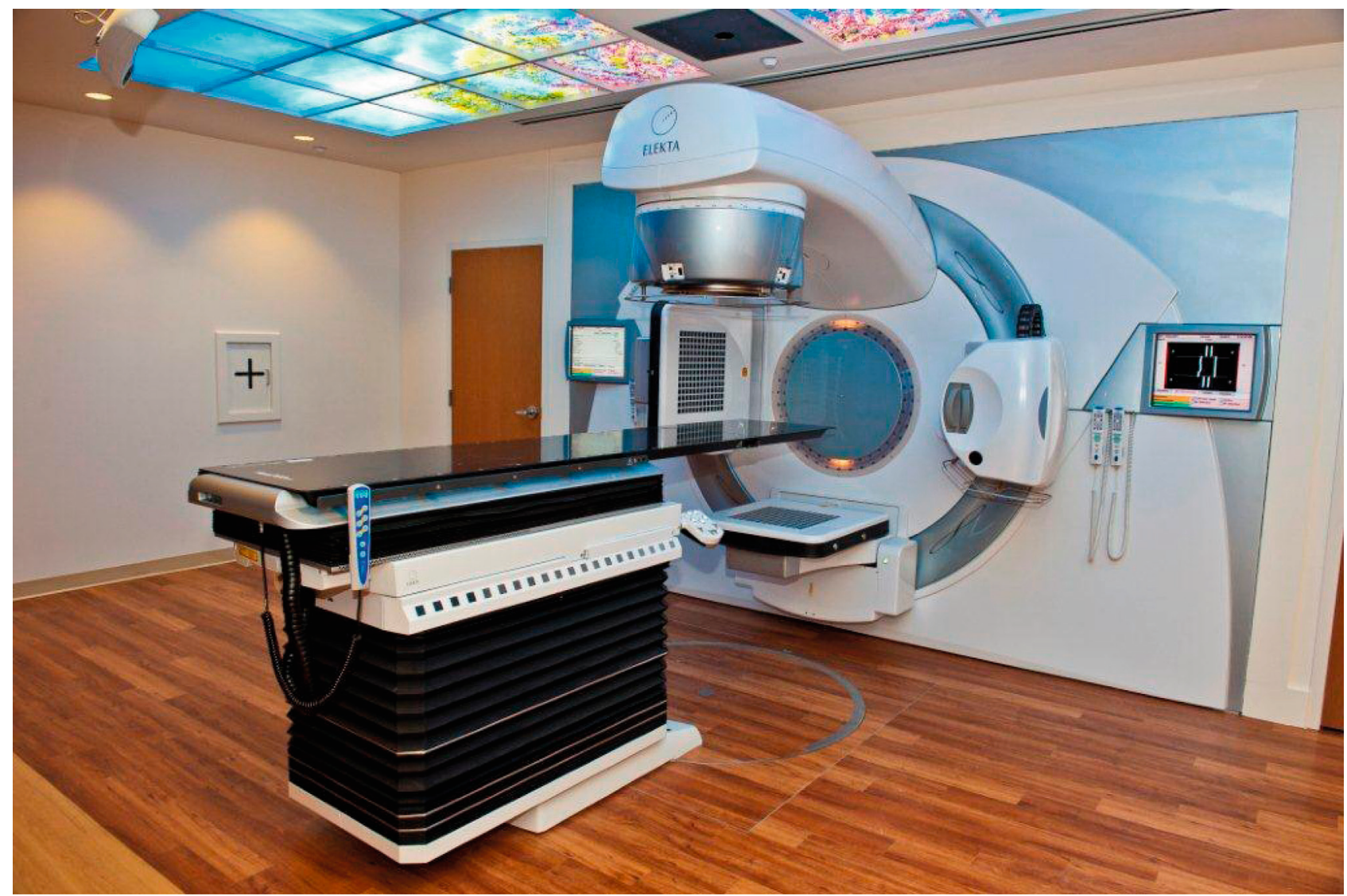

Slika 1. Linearni akcelerator

za planiranje dobiva trodimenzionalni anatomski model. Na tom tzv. virtualnom pacijentu precizno se planira zračenje jer se dobiva realan prikaz geometrijskih odnosa između tumora i okolnih organa te je moguće podešavanje geometrije polja zračenja, ali i distribucije doze zračenja prema nepravilnom obliku ciljnog volumena.

Naziv konformalna radioterapija (lat. conformalis - istog oblika) označava tehniku zračenja čijom se primjenom dobiva doza zračenja koja je svojim oblikom prilagođena obliku ciljnog volumena, što omogućava precizno apliciranje terapijske doze na tumor uz maksimalnu očuvanost organa rizika ${ }^{1}$.

$\mathrm{U}$ rane komplikacije (reakcije) ubrajamo one koje se javljaju unutar šest mjeseci od početka zračenja. One nastaju kao posljedica propadanja stanica koje se brzo množe (stanice rektuma i sluznice mjehura). Neke su od mogućih ranih reakcija kod zračenja zdjelice: mučnina, povraćanje, proljev, bol u zdjelici, teškoće s mokrenjem, gubitak teka i cistitis. Reakcije (komplikacije) se saniraju upotrebom uranoseptika, parenteralnom prehranom i dijetom.
Kasne komplikacije podrazumijevaju komplikacije koje se javljaju šest mjeseci nakon početka zračenja i javljaju se kao posljedica poremećene opskrbe krvlju zbog poslijeradijacijskog endarteritisa što rezultira propadanjem tkiva i njegovim nadomještanjem vezivnim tkivom (fibroza). Skupina kasnih reakcija obuhvaća: poteškoće s pražnjenjem crijeva, krvarenje iz mokraćnog mjehura i debelog crijeva, neplodnost, infarkt crijeva, opstrukcijske uropatije zbog stenoze mokraćovoda itd. ${ }^{4}$

Važno je napomenuti da učestalost komplikacija ovisi o dozi zračenja koju je primila pacijentica. Dakle, što je veća ukupna doza aplicirana u kraćem vremenu bit će i veći broj komplikacija. 


\section{Metode istraživanja}

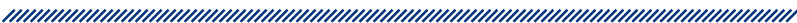

Pri istraživanju smo usporedili rezultate 20 pacijentica iz 2009. godine čije je teleterapijsko liječenje planirano 2D tehnikom s rezultatima 20 pacijentica iz 2011. godine čije je liječenje planirano 3D tehnikom. Sve su pacijentice bolovale od raka vrata maternice, i to stadija FIGO II.B i III.B.

Kod pacijentica kod kojih je primjenjivana 2D tehnika planiranja patohistološka dijagnoza (PHD) bila je uglavnom planocellulare, samo je kod dvije bila adenocarcinoma, četiri pacijentice nisu primile konkomitantnu terapiju (Cisplatin $70 \mathrm{mg} / \mathrm{m}^{2}$ ), a ostalih 16 jest. Pacijentice se u prosjeku zračilo sa 45 Gy u 25 frakcija (tri su zračene sa 50,4 Gy u 28 frakcija). U svih je pacijentica primijenjena HDR brahiterapija.

Kod 20 odabranih pacijentica čije je liječenje planirano 3D tehnikom patohistološka je dijagnoza bila jednaka kao i kod onih čije je liječenje planirano 2D tehnikom, dakle kod 18 je planocellulare, a kod ostale dvije adenocarcinoma. Sve su pacijentice primile konkomitantnu kemoterapiju i HDR brahiterapiju te je kod svih primijenjeno zračenje u iznosu 45 Gy u 25 frakcija.

\section{Rezultati istraživanja}

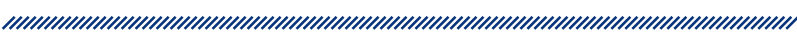

Dob pacijentica čije je liječenje planirano 2D tehnikom bila je između 40 i 74 godina (medijan 53 god.) Veličina tumora prije početka terapije bila je od 2 do $10 \mathrm{~cm}$ $(\mathrm{m}=4,4 \mathrm{~cm})$, a nakon terapije $2 \mathrm{do} 6 \mathrm{~cm}(\mathrm{~m}=3,3 \mathrm{~cm}), \mathrm{s}$ tim da se kod pet pacijentica tumor povukao. Pacijentice su u prosjeku primile 46,2 Gy u 26 frakcija te je kod svih primijenjena HDR brahiterapija.

$\mathrm{Na}$ prvom ginekološkom pregledu koji je učinjen tri mjeseca po terapiji učinjena je ginekološka i citološka kontrola čiji rezultati pokazuju da je jedna pacijentica imala rezidualnu bolest, šest pacijentica imalo slijepljenje rodnice, kod njih osam nalaz je bio potpuno uredan, a šest pacijentica imalo je uredan nalaz dok je citologija pokazivala upalne promjene.

Kontroli koja je učinjena šest mjeseci nakon terapije pristupilo je šest pacijentica, od kojih je jedna imala sli- jepljenje rodnice, dok joj je PAPA test bio uredan, dvije su pacijentice imale rezidualnu bolest, a citološki je nalaz pokazao i upalni proces te su tri pacijentice imale uredan ginekološki nalaz.

Na zadnjem ginekološkom pregledu koji je bio u različito vrijeme $(9,18,24,36$ ili 70 mjeseci nakon terapije), kojemu je pristupilo 18 pacijentica, utvrđeno je da je deset pacijentica imalo potpuno uredan nalaz te se više ne pokazuju znakovi bolesti, jedna je imala nekrozu, jedna je imala metastaze na $L 4$, nalazi četiri pacijentice pokazivali su slijepljenje, a dvije su imale degenerativne promjene rodnice.

Pacijentice čije je liječenje planirano 3D tehnikom bile su u dobi od 43 do 70 godina ( $m=59,1$ god.). Veličina tumora prije terapije bila je 3 do $6 \mathrm{~cm}(\mathrm{~m}=4 \mathrm{~cm})$. Sve su pacijentice ozračene istom dozom od $45 \mathrm{~Gy} \mathrm{u}$ 25 frakcija te su primile konkomitantnu kemoterapiju ( $\mathrm{m}=67 \mathrm{mg} / \mathrm{m}^{2} \mathrm{u}$ četiri puta). Kod svih je primijenjena HDR brahiterapija.

Nakon tri mjeseca od terapije učinjena je ginekološka i citološka kontrola: dvanaest pacijentica nije imalo znakova bolesti, ali je imalo slijepljenje rodnice, šest je imalo uredan nalaz, a dvije su imale rezidualnu bolest. Kod svih je pacijentica citologija pokazivala upalne promjene koje su posljedica iradijacije.

Drugi ginekološki i citološki pregled učinjen je šest mjeseci poslije terapije. Pola pacijentica, dakle njih deset, imalo je uredan nalaz, a ostalih deset imalo je slijepljenje. Kod drugog kontrolnog pregleda citologija je pokazivala upalne promjene kod osamnaest pacijentica, ostale dvije imale su uredan PAPA test.

Dvanaest mjeseci po završenoj terapiji pregledu je pristupilo 16 pacijentica, od kojih je osam imalo uredan nalaz, a kod osam je opisano slijepljenje rodnice. Kod svih je pacijentica koje su pristupile kontrolnom pregledu PAPA test ukazivao na upalne procese.

Na zadnjem pregledu koji je bio u prosjeku 26 mjeseci nakon terapije šesnaest je pacijentica imalo uredan nalaz, ali je kod četiri je opisano slijepljenje rodnice. Kod četiri ostale pacijentice pojavile su se metastaze u paraaortalnim limfnim čvorovima. 


\begin{tabular}{|c|c|c|c|c|}
\hline & $\begin{array}{l}\text { VELIČINA TUMORA } \\
\text { PRIJE TERAPIJE }\end{array}$ & $3 \mathrm{mj}$. & $6 \mathrm{mj}$ & ZADNJI PREGLED \\
\hline \multirow[t]{2}{*}{$2 \mathrm{D}$} & $4,4 \mathrm{~cm}$ & $\begin{array}{c}1 \mathrm{ca} \\
19 \mathrm{bez} c a\end{array}$ & $\begin{array}{c}2 \mathrm{ca} \\
4 \mathrm{bez} c a\end{array}$ & $\begin{array}{l}1 \text { nekroza } \\
1 \text { metha } \\
15 \text { bez ca }\end{array}$ \\
\hline & & 20 pacijentica & 6 pacijentica & 17 pacijentica \\
\hline \multirow[t]{2}{*}{$3 \mathrm{D}$} & $4,0 \mathrm{~cm}$ & $\begin{array}{l}2 \text { bez ca } \\
18 \text { bez ca }\end{array}$ & $\begin{array}{c}0 \mathrm{ca} \\
20 \mathrm{bez} c a\end{array}$ & $\begin{array}{c}0 \text { ca } \\
4 \text { metha } \\
16 \text { bez ca }\end{array}$ \\
\hline & & 20 pacijentica & 20 pacijentica & 20 pacijentica \\
\hline
\end{tabular}

\begin{tabular}{|c|c|c|c|}
\hline \multicolumn{5}{|c|}{ Tablica 2. Komplikacije radioterapije } \\
\hline & 3. mj. & $6 . \mathrm{mj}$. & ZADNJI PREGLED \\
\hline 2D & $\begin{array}{c}\text { 6 slijepljenja rodnice } \\
6 \text { colpitis }\end{array}$ & $\begin{array}{c}1 \text { slijepljenje } \\
2 \text { colpitis }\end{array}$ & $\begin{array}{c}\text { 4 slijepljenja } \\
\text { degenerativne promjene }\end{array}$ \\
\hline & 20 pacijentica & 6 pacijentica & 17 pacijentica \\
\hline 3D & 12 slijepljenja rodnice & 10 slijepljenja rodnice & 4 slijepljenja rodnice \\
\hline & 20 colpitis & 18 colpitis & 20 pacijentica \\
\hline
\end{tabular}

\section{Zaključak istraživanja}

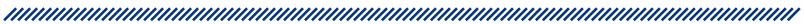

Provedeno istraživanje prikazuje reakciju na teleterapiju lokalno uznapredovalog raka vrata maternice, uz prihvatljive komplikacije. Istraživanje je provedeno kao sondaža podataka kako bi se utvrdilo postoje li razlike u pojavnosti ranih komplikacija teleterapije raka vrata maternice između pacijentica čije je liječenje planirano 2D i 3D tehnikom, što bi ukazalo na potrebu istraživanja na većem broju pacijentica. lako se očekivala znatna razlika između navedenih načina planiranja, kako u odgovoru na liječenje tako i u učestalosti i težini komplikacija, istraživanjem smo prikazali da se to ipak nije dogodilo.

\section{Zaključak}

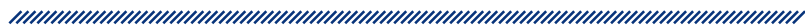

Radioterapija je, zahvaljujući uvođenju modernijih radioterapijskih uređaja, otišla korak naprijed prema željenom cilju. Osim unaprjeđenja aparature, iznimno je važna i neprestana edukacija profesionalnog osoblja koje sudjeluje u radioterapijskom procesu. Planiranje 3D tehnikom, odnosno konformalna radioterapija nova je metoda planiranja i provođenja radioterapije u Hrvatskoj koja upotrebom slika CT simulatora prenesenih u radioterapijski računalni sustav za planiranje omogućuje oblikovanje polja i snopova zračenja.

Najveća prednost je 3D planiranja precizno oblikovanje polja zračenja oko tumora, pošteda zdravog tkiva, primjena većih doza zračenja na tumor, manja toksičnost zdravog tkiva te veća preciznost kod namještanja bolesnika tijekom zračenja. Ako se na perkutanu terapiju nastavlja HDR brahiterapija, tada je 3D planiranje liječenja raka vrata maternice nužno radi određivanja ukupne doze u organima pod rizikom.

Kao i u svemu, postoje i loše strane 3D planiranja, kao što je primjerice dugotrajan postupak planiranja u odnosu na standardno 2D planiranje, no s obzirom na sve navedene prednosti koje smo naveli, konformalna je radioterapija današnja metoda izbora kod zračenja. 


\section{Literatura}

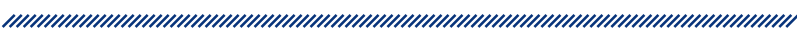

1. Šamija M, Krajina Z, Purišić A. Radioterapija. Zagreb: Nakladni zavod Globus, Klinika za tumore, Hrvatska liga protiv raka; 1996.

2. Turić M, Kolarić K, Eljuga D. Klinička onkologija. Zagreb: Globus; 1996.

3. Poliklinika Harni [internet]. Liječenje cervikalnog karcinoma. Dostupno na: http://www.poliklinika-harni.hr/Lijecenje-raka-vrata-maternice.aspx (pristupljeno 1.11.2017.).

4. Ćorušić A, Babić D, Šamija M, Šobat H. Ginekološka onkologija. Zagreb: Medicinska naklada; 2005. 


\section{DIFFERENCE IN THE INCIDENCE OF EARLY COMPLICATIONS OF TELETHERAPY OF CERVICAL CANCER BETWEEN 2D AND 3D PLANNED PATIENTS}

1 Dorjana Vidmar

2 Adem Hajredini

${ }^{1,2}$ Department of Gynaecology and Obstetrics, UHC Zagreb

\section{Abstract

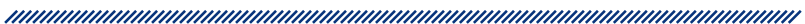

Treatment of cervical cancer depends on many factors and one of the treatment methods, besides surgical treatment, is radiotherapy. Radiotherapy is the use of ionizing radiation in the treatment of malignant and some benign diseases, aimed at destroying tumour cells with radiation, thus preserving surrounding healthy tissue. $2 \mathrm{D}$ radiotherapy and nowadays $3 \mathrm{D}$ radiotherapy are significant in this regard.

The aim of this research was to determine the difference in the incidence of early complications (reactions) of teletherapy between $2 \mathrm{D}$ planned patients and 3D planned patients. In this research, we compared the treatment results of 40 patients that had cervical cancer (stage IIB or IIIB) of which 20 patients were planned with 2D therapy and the remaining 20 were planned with $3 \mathrm{D}$ therapy. The research was conducted as a survey in order to determine if there is a difference in the incidence of early complications of teletherapy of cervical cancer between 2D and 3D planned patients, which would suggest the need for research on a larger number of patients. Although a significant difference between the aforementioned planning methods was expected, both in response to treatment and in the incidence of complications, this research showed that this did not happen.
Keywords: cervical cancer, 2D radiotherapy planning, 3D radiotherapy planning, early complications of teletherapy 